\title{
LUTHERANISM AND WELFARE STATE EXPERTISE. THE EXAMPLE OF HEIKKI WARIS
}

\author{
HANNA LINDBERG*
}

Åbo Akademi University

\begin{abstract}
The article examines the role of Christianity in the work of Heikki Waris (1901-1989), Professor of Social Policy at the University of Helsinki from 1948 to 1968. In studies on the historical foundations of different models of welfare, Lutheranism is often mentioned as a characteristic feature of the Nordic model. Previous research has, however, not to any larger extent examined the role of religion when analysing the work of so-called welfare experts. The article draws attention to importance of Christianity and the Lutheran Church, when analysing the work of a central architect of the Finnish welfare state. The article examines how Waris' background within the Settlement movement influenced his later academic and social political work. Furthermore, it looks at how Waris dealt with religion, Christianity, the Lutheran Church and faith in his work on social policy and social change. The connection between social policy and Christianity is analysed more closely, both in Waris' academic texts and the reports he wrote for the Lutheran Church on the challenges of the modern world.
\end{abstract}

KEY WORDS: Lutheranism, Finland, social policy, welfare state expertise, Heikki Waris

\section{Introduction}

When comparing the history of different welfare states, Lutheranism is often mentioned as a characteristic feature of the Nordic model of welfare (see e. g. Christiansen \& Markkola 2006: 10). Since the sixteenth century, all Nordic countries have been strongly dominated by the Lutheran faith, with the state and the church intertwined. The way the Lutheran faith and church have influenced the construction of the Nordic model of welfare has, however, been understood in different ways, and many studies have overlooked the role of religion in welfare state formation. Traditionally, welfare state scholars focusing on for example state formation or trade union development have not recognised Lutheranism or the Lutheran Church as integral parts of what constitutes the specific model of welfare adopted in the Nordic countries. Moreover, clergy or other religious figures have seldom been viewed as key players in the construction of the Nordic welfare states, whilst the Christian faith of other leading experts has rarely been the focus of welfare state scholarship.

* HANNA LINDBERG (PhD 2014, Åbo Akademi University, Finland) is postdoctoral researcher at the Department of History, Åbo Akademi University. Email: hanna.lindberg@abo.fi. 
In this article, I want to demonstrate the relationship between Lutheranism, social policy, and the role of experts in Finland during the mid-twentieth century. My focus is on the work of a central architect in the construction of the Finnish welfare state, Heikki Waris (1901-1989). Waris was professor of social policy at the University of Helsinki from 1948 to 1968, and an expert on social policy, social history and social change in post Second World War Finland. Waris also had a strong Christian faith and he was active in different Christian and ecumenical movements and organisations. Heikki Waris therefore stands out as an interesting example among the so-called welfare state experts of the twentieth century in the Nordic countries.

How did Waris' active Christian background influence his following academic and social political work? How did Waris understand the relationship between Christianity and social policy on the one hand, and between Christianity and the changing society on the other? I investigate these questions by focusing on three different, but integrated fields that Waris was engaged in. After discussing the interplay between experts, the welfare state and Lutheranism in Finland, I will look at Waris' involvement in the Settlement movement and how he conceptualised the relationship between Christianity and social work within the movement. Secondly, I will analyse Waris' academic work and texts written in non-Christian forums, to see how Christianity was discussed in relation to social policy, and which role he ascribed the church in theses texts. Thirdly, I will analyse the reports Waris wrote for the Lutheran Church of Finland in the 1960s and 1970s that dealt with the challenges the Lutheran Church faced in the industrialised world.

\section{The Role of Experts and the Role of Lutheranism in the Formation of the Welfare State}

Heikki Waris was active in many fields during the mid-nineteenth century, but is foremost known as Finland's first professor of Social Policy and as the one who developed Social Policy as an academic field in Finland. He thereby also influenced how the Finnish welfare state was conceived and constructed in post-war Finland (Lindberg 2014: 57-64). The role of experts has often been emphasised in welfare state research. According to Åsa Lundqvist and Klaus Petersen, expert knowledge has been vital throughout the twentieth century in forming the welfare state and shaping modern society. From the 1930s onwards, a fruitful interplay between the state, bureaucrats and experts, such as scientists, doctors and architects, was formed in the Nordic countries. According to Lundqvist and Petersen, the role of experts was emphasised partly as a way to depoliticise social policy, making it more a matter of scientific rationality than of political ideology (Lundqvist \& Petersen 2010: 10, 13-15).

To analyse the relationship between welfare state development and expert knowledge scholars have often adopted a biographical approach, focusing on spe- 
cific experts and showing how these experts participated in the formation of the welfare state throughout the twentieth century (see e. g. Berg 2009; Hirdman 1989). Most notable among these experts is the Swedish couple Gunnar and Alva Myrdal, who through their scientific and political work became key players in Swedish social policy in the twentieth century. However, the extent to which specific experts could gain actual power in social political decision-making has been debated (see e. g. Rothstein 1998: 171-174; Saari 1994). Lundqvist and Petersen stress that although experts were eager to take a leading role they were often hindered by politicians and the general public, who did not agree with their visions (Lundqvist \& Petersen 2010: 14-15).

As mentioned above, scholars have seldom combined the role of expert knowledge with that of the role of Lutheranism in their analysis of the formation of the Nordic welfare states. When religion was first emphasised in the 1990s as contributing to how welfare was distributed and different welfare models constructed, countries dominated by Catholicism were studied to demonstrate the relationship between religion and welfare state formation. Scholars such as Kees van Kersbergen showed how the Catholic faith and Christian Democratic parties formed social policy by focusing on family values and conservative social norms (van Kersbergen 1995; see also Markkola \& Naumann 2014: 4).

It is not until lately that also Protestantism, and specifically Lutheranism and the Lutheran Church has been recognised as participating in the formation of the welfare state. This might seem surprising, considering that the Lutheran faith has had a dominant position in all Nordic countries. However, according to Pirjo Markkola and Ingela K. Naumann, an explanation might be found in the relatively low profile of the Lutheran Church (Markkola \& Naumann 2014: 2). Despite its hegemonic position and high church membership, the Lutheran Church has not profiled itself as a major political or societal player, thus leading to scholars not recognising the more subtle ways in which the Lutheran faith and the Lutheran Church have influenced welfare states.

Some scholars have, however, emphasised Lutheranism in their studies of the welfare state, but the role of Lutheranism and the Lutheran Church has been understood in different ways. Henrik Stenius has emphasised the common ideology of Lutheranism and Nordic political culture, stemming from the unification of state and church during the reformation in the sixteenth century. Stenius argues that Lutheranism introduced conformity as an ideal, which also meant that the state was held in high regard and that the citizens were law-abiding. Later on, this contributed to a high acceptance of an interventionist welfare state (Stenius 1997: 161-163, 171). Uffe Østergård has argued that the dominance of the Lutheran Church and the Lutheran faith in the Nordic countries was a prerequisite for the welfare state. Lutheranism was maybe the greatest component in the homogeneity of the Nordic countries, which in turn enabled the creation of the welfare state (Østergård 1997: 69). 
Other scholars have focused on early welfare institutions that were locally administered by the parishes, and that later on merged into state driven means of welfare. According to Pirjo Markkola, the case of poor relief is a good example of how Lutheran doctrines changed on the one hand the view of aiding the poor, and on the other how early forms of social security was administered. By arguing that salvation was received through faith and not through deeds, such as giving alms, poor relief was transformed from an individual to a collective responsibility, which is a cornerstone in the Nordic welfare model. Poor relief was up until the nineteenth century administered on a local level, with parishes taking great responsibility of the welfare of its members (Markkola 2011: 106-110).

Did the Lutheran Church and its representatives play an active role in forming social policies or welfare state ideology? Most contributions to the issue of Lutheranism and the Nordic welfare states point to the ideological similarities between Lutheranism and the welfare state or the historical foundations set by the Lutheran Church for the welfare state. Scholars focusing on the direct link between the church and modern welfare state formation have to a greater extent drawn attention to the scepticism church leaders showed towards the welfare state. Most prominent was the criticism expressed by the Norwegian bishop Eivind Berggrav after the Second World War, as shown by the church historian Aud V. Tønnessen. In the $1940 \mathrm{~s}$ and $1950 \mathrm{~s}$, Berggrav vehemently criticised the welfare state for political totalitarianism and for ignoring the church and the family as welfare providers (Tønnessen 2000; Tønnessen 2014).

Berggrav's criticism also spread among the Finnish clergy in the late 1950s. One of the main Finnish critics was the bishop Eino Sormunen, who based on Berggrav's teachings published a book in 1958 where he warned against the centralisation of power that the welfare state entailed. Sormunen did, however, recognise the need for social security and the fact that the church alone could not provide it for all citizens. Moreover, he did not condemn all forms of social policy, such as social insurances and social benefits. Most problematic in his view was the institutionalisation of care, such as childcare and old people's homes, that made family responsibilities, and especially those of the mother's, a matter of state affair. Similar criticism towards the welfare state was also raised by other members of the clergy in the 1960s (Markkola 2014: 74-77). Pirjo Markkola has argued that when the church in Finland took a clear stance in matters of welfare, it was issues of family that arose most attention. This is not only visible in Sormunen's critique of the welfare state, but also in the concrete social work the church initiated in the 1940 s and $1950 \mathrm{~s}$, as well as the committee reports initiated by the Lutheran Church in the $1950 \mathrm{~s}$ and $1960 \mathrm{~s}$ on the changing societal role of the church (Markkola 2014).

The conclusion of scholars focusing on the clergy's involvement in welfare state development has been that although commenting on welfare state development, they did not take an active political role in actually forming the welfare state 
(Markkola 2011: 104). The role of experts and the role of Lutheranism, however, can also be understood in another way, that is by focusing on the Christian faith and the Christian background of leading experts on social policy, or the importance these experts assigned Christian social work or the Christian heritage of the welfare state. When recounting the biography of Lord William Beveridge, his background within the Settlement movement is often mentioned. Beveridge worked as a sub-warden at the original settlement Toynbee Hall from 1903 to 1905 , with the purpose to study in practice what he had learnt at university. Beveridge's biographer José Harris also writes that Beveridge was openly critical towards many parts of the Settlement movement, especially its focus on individual charity, while Beveridge viewed settlement work chiefly as a means to greater social development. Although Harris accounts for Beveridge's Christian belief, and stresses that Beveridge's time at Toynbee Hall moulded him as a social reformer, he describes Beveridge's involvement in the Settlement movement as an intellectual pursuit, and not as religious one (Harris 1977: 28-30, 43, 48-50, 55, 59-60). Nordic scholars focusing on individual social reformers have, however, not paid any attention to questions of faith and the role of religion, giving the overall picture of religion, Christianity and the Lutheran faith as not being of any significance to Nordic social reformers. As I will show in the following chapters, the case of Heikki Waris alters the picture.

\section{Heikki Waris and the Settlement Movement}

Like William Beveridge, Heikki Waris became active in the Settlement movement as a young man, and his work within the Settlement movement can be understood as the foundation for his later pursuits (Nieminen 1981: 18; Uusi-Rauva 2008: 14). The concept of the settlement, where privileged youth got first-hand experience with the conditions of the working class by socially aiding and educating them, developed in London's East End, where Toynbee Hall was established in 1884 by a group of university teachers and clergymen, with Canon Samuel Barnett as its primary leader. The Settlement movement quickly spread to other European countries, as well as America, with Hull House in Chicago, founded by Jane Addams as another leading settlement (Waris 1926: 3-4).

The Settlement movement was, however, not a uniform organisation and developed along different paths in different countries (Sipilä 1989: 36). Furthermore, the relationship between the settlements and Christianity varied. Some settlements worked within the confines of the church, others loosely attached to it, and some with no link to Christianity or a certain Christian denomination (Waris 1926: 5-6). Scholars investigating different national settlements have, however, pointed out some similar features in the early Settlement movement. It was primarily a socially conservative movement, based on strong class divisions, where members of the middle and upper class installed their social beliefs in the working-class population (Harris 1977: 45; Varsa, Szikra \& Juhász 2009: 135-136). In 
studying the Hungarian Settlement movement, Eszter Varsa, Dorottya Szikra, and Juhász Borbála have furthermore emphasised the gender and ethnic/race bias of the Settlement movement. The organisation was heavily drawn along gender lines, with women only playing a marginal role. With the emergence of antiSemitism during the first half of the twentieth century, the Christian foundation of the movement was closely linked to nationalism and used as a means for excluding people along racial lines (Varsa, Szikra \& Juhász 2009: 136-139).

The Settlement movement also reached Finland, and there were some endeavours as early as the 1880 s and 1890 s to implement the settlement idea in Finland. A permanent foundation for the movement was established in the working-class area of Kallio in Helsinki in 1919. The founders of the Kalliola Settlement, professor and later bishop Jaakko Gummerus and reverend Sigfrid Sirenius, had both lived and travelled in England, and learnt about settlement work. The purpose of introducing the Settlement movement in Finland was according to the Finnish church historian Sami Uusi-Rauva twofold: Sirenius and Gummerus wanted to install the Christian faith in the working class, and help them with their social destitution (Uusi-Rauva, 2008: 9-10). This was mainly done through adult education, youth clubs and religious activities such as Sunday schools and Bible circles, with only smaller ventures in to health care and social work (Waris 1929: 21-22).

Waris, who had reached a Christian awakening as a student at the University of Helsinki, was introduced to the Kalliola settlement through his friend Ilmari Salonen, who would later become the Archbishop of Finland with the name Ilmari Salomies (Nieminen 1981: 17-18; Repo 2011: 97). Waris was first engaged in 1920 as a voluntary youth club leader, and three years later as the director of the Free institute that gave adult education. The Settlement movement also spread to other parts of Finland, with the Toukola settlement opening its doors in Viipuri in 1924 and the Rovala settlement in Rovaniemi in 1926 being among the first (Waris 1929: 14-16).

The Finnish Settlement movement's relationship to the church and the university resembled that of the original English settlements. The settlements connection to the Lutheran Church of Finland was close, as the clergy served as wardens of the settlements, and Gummerus, bishop of Porvoo and later Tampere, was the president of the Settlement society. Although the settlements co-operated with local parishes, they were not administered by the church (Waris 1929: 17). University students were also engaged in the work of the settlements, especially within adult education, but there was no official arrangement between for example the University of Helsinki and the Kalliola settlement (Waris 1929: 32-33).

Waris quickly became one of the leading figures at the Kalliola settlement, developing and diversifying the activities of the Free institute. Waris was also pivotal in defining the purpose of the Finnish Settlement movement. In a text written for the third international conference of settlements in the Netherlands in 1929, Waris presented the Finnish Settlement movement to an international audience, 
Waris discussed the relationship between Christianity and the social work done by the Settlement movement. In the text, Waris stressed that the need for the Settlement movement originated from the church's neglect of the working class. In a country with 98 percent of the population belonging to the Lutheran Church, the church had not kept pace with the rapid social and economic changes that had occurred in the late nineteenth century, with large-scale industrialisation and urbanisation. Therefore, people were becoming more and more estranged from Christian teachings, and the gap between the labour movement and the church grew. This was the starting point for the Settlement movement in Finland, according to Waris, but he simultaneously emphasised another social division that was prominent in Finland in the late 1910s. The Finnish civil war of 1918 had created a deep wedge between the working and the middle classes, and the Settlement movement was a way 'to mitigate the bitterness between the different classes of society'. This was achieved by creating personal contacts and close co-operation between people of different backgrounds that were conveyed through the Settlement movement (Waris 1929: 7-8).

Waris, however, did not present this as an easy task. The very first steps towards settlement work and enlightening the working class of Christian teachings through public meetings and discussions met with great suspicion and animosity towards the clergy. However, opinions quickly changed, and the negative attitudes of the working class toward the Settlement movement waned. According to Waris this was a result of two parallel processes, where the labour movement realised that Christianity was not the same thing as the church, and middle class realised that the working class was not the same thing as the labour movement. In other words, the working class was depoliticised and the Settlement movement deinstitutionalised (Waris 1929: 18). This was a result of the work of the Settlement movement moving from mass lectures to small-scale, individual education (Waris 1929: 11-13). Throughout the text, Waris emphasised the personal contacts that were formed between the representatives of the Settlement movement and members of the working class, and that personal service was the key to education and religious enlightenment. Waris also stressed the personal Christian faith of the workers of the settlements, and that this was the driving force behind their work (Waris 1929: 17-19, 24).

When discussing the practical work of the Settlement movement, Waris put more emphasis on the educational work and youth work than he did on the concrete religious work of the settlements. Sami Uusi-Rauva, who has studied Waris involvement in the Settlement movement, has demonstrated how Waris' vision of the Settlement movement differed from that of other leading figures, such as Sirenius and Arvo Tolsa, pastor and activist within the North Finnish settlement. While other settlement leaders emphasised the Christian teachings of the Settlement movement, Waris stressed the practical work that the settlements were engaged in, and the need for settlements at a time when that kind of work was not 
successfully being done by other actors. In these debates, Waris stressed that the church was a people's church (kansankirkko), and that the work of the Settlement movement was a natural part of the duty of the church (Uusi-Rauva 2008: 17-24). In the text written in 1929, the practical work and Christian teachings of the Settlement movement were not, however presented as separate fields of work. Especially within work done amongst the youth, the Christian message to the practical work was emphasised. Waris stressed that the Settlement movement provided working-class youth with wholesome activities that were based on Christian teachings, and thereby providing them with moral resistance (Waris 1929: 31).

\section{Christianity and Academic Work}

Waris' involvement in the Settlement movement had a direct influence on his academic career. Originally a historian, Waris began work on his doctoral dissertation in the late 1920s. In the dissertation Waris studied the rise of the workingclass community in the area of Kallio and Sörnäinen in Helsinki in the second half of the nineteenth century, when Finland was industrialising. Written within the Kulturgeschichte tradition and influenced by the Chicago school of sociology, the dissertation focused on the social structure and the social conditions of a specific working-class community. Waris studied in detail the process of how the community was formed, its demographic and social structure, and social conditions, such as living conditions, nativity, mortality, sickness and health care. The dissertation was ground breaking within Finnish historiography and would later become a classic study within social, labour and urban history. Also within Finnish sociology it is often mentioned as a predecessor, as it was the first study in Finland to adopt American sociology (Haapala 1989: 116; Alapuro \& Alestalo 1992: 123-126).

In the very first paragraph of the dissertation Waris testified to the influence of the Settlement movement. Waris wrote that his interest for the topic of the dissertation arose while he worked at the Kalliola settlement. Waris stressed that it was through his personal contacts and by working side-by-side with working-class men of different ages that he learnt to know and understand a mental life (sielunelämä̈̈), which had previously been unknown to him (Waris 1932: 1). Religion or the role of Christianity was not a topic that Waris dealt with specifically in the dissertation, but he alluded to the loss of the Christian faith when explaining some of the conditions in the community. The restriction of children, that grew more common towards the end of the decade, was one example of how a Christian way of life gave way to a secularised one (Waris 1932: 126). Waris also wrote about the concrete work of the parishes and wrote with admiration about the health care provided and educational work done by the deaconesses in the community (Waris 1934: 80-82).

Waris' experience within the Settlement movement had a more indirect influence on the dissertation. As discussed in the previous chapter, Waris saw the work done within the Kalliola settlement as a way to bridge the gap between the work- 
ing and the middle class, which had grown as a consequence of the Finnish Civil War in 1918. This was done by depoliticising the working class. The dissertation can be interpreted as a further tool to bridge the gap and to add to the knowledge of the working class, not by emphasising political conflicts, but by ignoring them. Waris did not deal with power relations and the political awakening of the working class, and the destitution of the working class was not explained by employeremployee relations. Instead, the poverty and misery of the working class were seen as results of sociological laws that followed upon poor housing, nutrition and health care (Waris 1934: 8, 29-30, 163). Later scholars have regarded this as a way to depoliticise the conditions of the working class and to increase understanding for their situation (se e. g. Alapuro \& Alestalo 1992: 126; Haapala 1986: 268-269).

During the 1930s, Waris gravitated from the discipline of history to the emerging social sciences and was through a visit to Chicago in 1934 one of the first Finnish scholars to have contact with American social scientists who would dominate the field after the Second World War (Alapuro \& Alestalo 1992: 124; Allardt 1984: 1). The war marked a clear shift within Finnish social science, especially within the field of sociology. The anthropological research that had dominated before the war gave quickly way for studies primarily adopting quantitative methods and focusing on the modern industrialised and urbanised society. The new position of the social sciences was marked by the establishment of the Faculty of Social Sciences at the University of Helsinki in 1945. Social Policy was among the new disciplines introduced at the faculty and Heikki Waris was appointed as the discipline's first professor in 1948 (Lindberg 2014: 51-52).

Waris held the professorship during a formative period in Finnish history, and especially in the history of the welfare state. After the Second World War, Finland was still largely an agrarian country, with economic struggles following upon the losses to the Soviet Union in the Winter and Continuation Wars. Although Finland did not experience a similar economic growth as the other Nordic countries in the $1950 \mathrm{~s}$, which enabled them to grow into welfare states, the country still slowly transformed into a universal welfare state during the mid-twentieth century, following the example of its Nordic neighbours. Focus was on family policy, with for example the introduction of the child benefit in 1948 which was awarded all families irrespective of their economic status, as well as pensions, with the pension system completely transformed in the late 1950s and early 1960s.

Heikki Waris published one of his seminal books, Suomalaisen yhteiskunnan rakenne [The Structure of Finnish Society], the same year as he officially acquired the professorship in social policy, i. e. 1948. The book was the first text book about the social structure of Finland and it was primarily meant to be used in the education of social scientists. The book was also a good example of what would become leading themes in many of Waris' publications. Firstly, he presented Finnish society and the Finnish population as homogenous and living in social peace. The homogeneity of the Finnish population was displayed by a number of different 
factors, such as the economic, racial and linguistic features of Finnish society. A strong component was also the religious homogeneity, with 96 percent of the population adhering to the Lutheran Church. According to Waris, this meant that Finland was religiously one of the most homogenous countries in the world (Waris 1948: 58). Waris was not only stating a fact but building his case of Finland as a homogenous unity, which he regarded as one of the best features of Finnish society when compared to other nations (Waris 1948: 24).

Secondly, the grand narrative of the book was how Finland had developed from a stagnant agrarian society to a modern, industrialised country. When describing how Finland in a matter of one hundred years had transformed from a stagnant agrarian society into a modern democracy, Waris emphasised the industrialisation of Finland in the late nineteenth century as the starting point of all economic, social and technological change. The industrialisation that started in full scale from the 1860s was presented as a big bang that changed Finnish society to its core. In a later publication, Waris wrote about what implications this had for the Lutheran Church in Finland and how its leaders dealt with the challenges of the industrialised world. The challenges were both immediate and long-term, but they all stemmed from the loss of the Christian faith and the Christian way of living. Some challenges were not directly visible to the contemporaries, and therefore the church did not understand to react to them. Waris once again especially mentioned the will to control the number of children being born into families. A more immediate threat was the loss of influence from the church over the working class, and the problem with uniting religion with politics. In this struggle, Waris praised the Settlement movement as the best bridge between them (Waris 1963).

In Suomalaisen yhteiskunnan rakenne Waris presented Lutheranism not only as the dominating religious confession of the Finnish population, but also as a cultural factor that transcended society in different ways. Many social structures descended from the church and its local administration. This was especially evident in social policy and social work. Waris stressed the responsibility of the church in caring for the poor and the institutions that emerged from this responsibility (Waris, 1948: 59). In another influential text book, Suomalaisen yhteiskunnan sosiaalipolitiikka [The Social Policy of Finnish Society] from 1961, Waris also stressed the historical foundations of social work, and that they descended from the church (Waris 1961: 157-158).

The Lutheran Church and the Christian faith were therefore understood as a foundation for the modern welfare state. However, the church and its various tasks were not only presented as the institutional background of modern social policy, Waris also explained the need for social policy by referring to the Bible and Christian teachings. In Suomalaisen yhteiskunnan sosiaalipolitiikka Waris cited the Acts of the Apostles 4:35 to explain why the church felt a responsibility to aid those who could not take care of themselves (Waris 1961: 157-158). Furthermore, Waris also explained modern social policy as based on the teachings of the Bible. 
In Suomalaisen yhteiskunnan rakenne, Waris wrote extensively on the mentally and physically disabled and the social political measures used to care for them. As an argument for caring for those whose mental disability was so great that they could never provide for themselves, Waris stated that it was duty for every civilized country to care for them, and that this was dictated by the Christian doctrine of love for one's neighbour (Waris 1948: 39). In the book from 1948, Waris was otherwise strict in his suggestions for treatment of the feebleminded and recommended eugenic measures to protect society from the dangers that mentally inferior individuals posed (Waris 1948: 39-40).

Waris' list of publications is extensive. Not all texts were academic and many articles were meant for the (educated) general public. However, also these texts dealt with similar themes as the academic texts, and for the most part Waris wrote in his capacity as professor of Social Policy. In the late 1940s and early 1950s Waris contributed with several articles on social change and social policy in Suomalainen Suomi [Finnish Finland], a journal on culture and current affairs. In the articles, Christianity and the topic of faith had a much more visible role than they had in Waris' academic texts. In an article on social change of the twentieth century in the western world, Waris mentioned industrialisation, rationalisation, mobility and mechanisation as developments that had greatly transformed society. These developments meant that the standard of living had increased significantly, and that the bridge between people of different classes decreased. However, despite the great steps that humankind had taken, Waris claimed that people lived in disbelief and were pessimistic about the future. According to Waris, the moral development of society lagged badly behind all other progress, which was visible on a global scale, as well as within people's private lives. To explain the contradiction between societal and moral development Waris referred to scholars such as Arnold J. Toynbee and Pitirim Sorokin, who ascribed this to the loss of religion and faith. The objective of the article was therefore to point to the necessity of Christianity and the Christian faith to guide Finnish society in the modern world (Waris 1950).

While Christianity was subtly included in the more purely academic texts, Waris wrote directly and with emphasis on the need for Christian faith in the modern world in his texts in Suomalainen Suomi. This also extended to texts that dealt exclusively with social policy. In an article on current developments within social policy and the aim to alleviate social inequality, Waris dealt thoroughly with the social and economic implications of the redistribution of wealth. Waris finished the article by stating that the state was not the only institution that provided help, and that there was a grave need for personal contacts to alleviate social distress. The Christian responsibility to care for the weak was emphasised as a necessity in the modern world. Faith and Christianity were therefore presented as necessary complements to social policy (Waris 1951). 


\section{Expert Knowledge for the Lutheran Church}

By the late 1950s Heikki Waris had become an influential scholar. Social Policy as an academic subject had grown into a leading subject amongst the social sciences, and Waris was regarded as a leading expert in social policy and social change. Waris' influence was not confined to the academic world. His expertise on the social political field was further strengthened through his chairmanship in the Social Policy Association between 1949 and 1963. The association was actively involved in forming and influencing Finnish social policy. Waris never publicly supported a specific political party or ventured into politics, but for a short period of time he exercised some direct political power. In 1957 and 1958 Waris served as minister of social affairs in Rainer von Fieandt's caretaker government (RainioNiemi 2009; Riihinen 2009).

Waris influence also stretched to the Lutheran Church of Finland. Although Waris never held an official position within the church, he was entrusted to lead two investigations in the 1950s, 1960s and 1970s into the changing role of the church in modern society. In 1958, the General Synod dealt with how Finland was rapidly changing and what challenges this entailed for the church. The General Synod decided to take concrete action and a committee was appointed to map out the problems facing the Lutheran Church in Finland in the modern world (Juva 1976: 195). The purpose was to give recommendations for how the church should deal with these problems. Waris was appointed as chair of the committee that also consisted of one layperson, three pastors and a theologian as secretary. The research for the report was conducted in collaboration with the institute of social policy at University of Helsinki, which produced studies on for example church activity and church resignation. The results presented at the General Synod in 1963 were therefore of high scientific quality, and the studies conducted in connection with Waris' commission were predecessors within the field of sociology of religion in Finland (Sundback 1991: 46-55).

Throughout the report, Waris' conception of societal change is apparent. Similar to Waris' description of Finland in Suomalaisen yhteiskunnan rakenne, the report painted a picture of Finnish society as completely transformed after the industrial revolution. The former static agrarian society had over a period of a century changed into an industrial, mechanised, urban society. The report especially focused on the rise of the working class, urbanisation, an increasing number of young people, and the changing role of the family as the most significant changes for the Lutheran Church. With the changes that had occurred, young, urban, working-class individuals had become estranged from the church and Christian teachings, and the report dealt with how this group could be reintroduced to the $\operatorname{church}(* * * 1963)$.

In the report, change was not portrayed as something negative. Religion stood for tradition, but the report stated that it was sometimes good to break from tradition, as religion that was based on tradition alone could prevent people from com- 
ing to personal belief and attaining religious maturity (*** 1963: 29). The report also acknowledged the higher standard of living that had been brought about by economic, technical and social change. With better health care, better education, social policy and democracy, Finland was becoming a 'prosperity society' (välståndssamhälle) (*** 1963: 9). However, this did not mean that the need for pastoral care had diminished, which was evident from the higher numbers of suicides and cases of mental illness (*** 1963: 22-23).

How should the church deal with the problems and challenges posed by the industrialised, urban society? The commission's task was not only to map out the problems, but also to give recommendations for how these problems could be solved. The emphasis was on structural reform, education and research. Migration from the countryside to cities and rural centres meant that the structure of the parishes should be revised. The education of church employees needed to be complemented throughout their careers, to better familiarise them with contemporary problems that might arise. The report also suggested that the church should directly promote research, and that a research institute could be founded. This proposal was the most lasting influence of Waris' committee, as the Church Research Institute was founded in 1969 with Waris as chairman of the board (Juva 1976: 208-209; Nieminen 1981: 28).

Although the development of social policy was not at the forefront of the committee's work, the report commented upon social policy as an integral part of modern Finnish society and pointed out that the foundation of social policy was found within the church. The connection between the church and social policy was of greater concern in a later report by Waris for the Lutheran Church of Finland. At the episcopal conference in October 1970, Waris was given the task to map out the social ethical problems that Christians and the church of Finland faced in the modern world. By the 1970s, Waris was a prominent expert for the Lutheran Church, and was also a member of the working committee of the Christian Peace Conference, an international organization that promoted peace in the name of Christianity. The primary purpose of the task given to Waris by the bishops in 1970 was not to give concrete suggestions for how the church should deal with these problems. The pamphlet Waris wrote on the social ethical problems was more of a philosophical character, and supposed to work as a discussions opener for the church (Waris 1971: 7-8).

In the spirit of the report Waris chaired on the challenges facing the church in the modern, urban world, Waris discussed how society had changed during the twentieth century. The focus in the text was, however, on specifying different problems for the Lutheran Church of Finland, explaining their character, and defining which problems were greater than others. Waris listed a huge number of different problems facing Christians in the modern world, ranging from the personal and the national to the global. In several passages Waris discussed the connection between Christianity, social policy, and the development of the welfare 
state. Waris stated that the church was non-political, but that this did not mean that the church should not take sides. According to Waris the church should in all instances take the side of the weak, and be aware of the privileges of the affluent. Social justice should therefore always be a goal for the church (Waris 1971: 32-33).

One of the leading themes in the pamphlet was the Christian teaching of love of one's neighbour, which according to Waris also supported the development of social policy. Once again, Waris commented on the fact that the modern system of social policy was rooted in the work of the church and its parishes. Although many duties had been taken over by the state and the municipalities, the church still offered social help to those in need. The sides to social policy that the church was not involved in, that is income transfers such as grants and benefits, were according to Waris a great social ethical accomplishment for Finland that supported the idea of love of one's neighbour (Waris 1971: 34-35). Thus, Waris saw a direct link between Christianity and comprehensive welfare that rested both on income redistribution and social services.

Although Waris clearly stated that the growing welfare state was supported by the Christian ideal of love of one's neighbour, he was cautious about the extent to which the church should be involved in the development of social policy. The church had not taken an active part in a number of debates on social policy, and according to Waris the church should not do this as its representatives lacked the competence to do it (Waris 1971: 46).

\section{Conclusion}

Many scholars have drawn attention to the role of the Lutheran Church and the Lutheran faith in the development of the Nordic model of welfare. Rarely, however, has an analysis of the role of religion been included in studies focusing on individual experts and their part in the formation of the welfare state. By focusing on the work of the Finnish social scientist Heikki Waris, I have analysed on the one hand how Christianity influenced Waris' academic pursuits, and on the other, how Waris conceived the relationship between social policy and Christianity.

Waris' interest in social issues stemmed from his activity in the Settlement movement, a Christian social movement were members of the middle class offered education and social help to the working class. With the purpose to reintroduce the Christian faith to workers in the area of Kallio and Sörnäinen in Helsinki, and to bridge the gap between different social strata, Waris became an influential figure in the beginning phases of the Settlement movement. Waris' background within the Settlement movement could be seen in different parts of Waris's later academic work. It was evident in his historical work on the birth of the workingclass community of Kallio, but it was also visible by the way he portrayed Finnish society as unified and the Finnish people as homogenous in his later work on social policy and social change. 
Although Waris rarely wrote specifically on religion in his work on social policy, the connection between social policy, Christianity and the Lutheran Church of Finland was touched upon repeatedly and explained in different ways. The Lutheran Church was understood as a foundation for the modern form of social security offered by the Finnish state, as aiding the poor was a duty set by the Bible. Christian teachings such as love of one's neighbour were a motivation for social policy and for a civilised state to care for those most in need. Furthermore, Christian institutions were seen as complements to state-provided social policy and social services.

In the reports Waris conducted for the Lutheran Church of Finland on challenges that the church was facing in the modern industrialised world Waris commented more extensively on the relationship between social policy, Christianity and the Church. He clearly stated that Christian teachings supported the development of social policies. The church could not be idle to the destitution of the poor and modern social policy, social services as well as income redistribution in the form of grants and benefits were achievements in the name of love of one's neighbour.

\section{Bibliography}

Alapuro R and Alestalo M (1992) Konkreettinen sosiaalitutkimus. In Alapuro R, Alestalo M, and Haavio-Mannila E (eds) Suomalaisen sosiologian historia. Helsinki: WSOY, pp. 77-148.

Allardt E (1984) American Impact on Science and Higher Education in Finland. Helsinki: University of Helsinki.

Berg A (2009) Den gränslösa hälsan. Signe och Axel Höijer, folkhälsan och expertisen. Uppsala: Acta Universitatis Upsaliensis.

Christiansen NF and Markkola P (2006) Introduction. In Christiansen NF, Petersen K, Edling N, and Haave $\mathrm{P}$ (eds) The Nordic Model of Welfare. A Historical Reappraisal. Copenhagen: Museum Tusculanum Press, pp. 9-29.

Haapala P (1986) Muotia vai ei?-Suomalaisen sosiaalihistorian muuttuvat näkökulmat. In Kiuasmaa et al (ed) Yksilö ja yhteiskunnan muutos. Juhlakirja Viljo Rasilan täyttäessä 60 vuotta 22.1.1986. Tampere: Tampereen yliopisto, pp. 263276.

Haapala P (1989) Sosiaalihistoria: johdatus tutkimukseen. Helsinki: Suomen historiallinen seura.

Harris J (1977) William Beveridge. A Biography. Oxford: Clarendon Press.

Hirdman Y (1989) Att lägga livet till rätta—studier i svensk folkhemspolitik. Stockholm: Carlssons bokförlag.

Juva M (1976) Kirkon parlamentti. Suomen kirkolliskokousten historia 1876-1976. Helsinki: Otava. 
*** (1963) Kyrkan i det nutida samhället. Betänkande utarbetat av en av det adertonde allmänna kyrkomötet tillsatt kommitté till kyrkomötet 196. Pieksämäki: Sisälähetysseuran Raamattutalon kirjapaino.

Lindberg H (2014) Mannen som objekt och problem. Heikki Waris och betydelsen av kön $i$ vetenskaplig socialpolitik, cca 1930-1970. Åbo: Åbo Akademis förlag.

Lundqvist $\AA$ and Petersen K (2010) Experts, Knowledge, and the Nordic Welfare States. An Introduction. In Lundqvist $\AA$ and Petersen $\mathrm{K}$ (eds) In Experts We Trust. Knowledge, Politics, and Bureaucracy in Nordic Welfare States. Odense: University Press of Southern Denmark, pp. 9-31.

Markkola P (2011) The Lutheran Nordic welfare states. In Kettunen P and Petersen K (eds) Beyond Welfare State Models. Transnational Historical Perspectives on Social Policy. Cheltenham: Edward Elgar, pp. 102-118.

Markkola P (2014) Focusing on the Family: The Lutheran Church and the Making of the Nordic Welfare State in Finland, 1940s to 1960s. Journal of State and Church 56(1): 60-80.

Markkola P and Naumann IK (2014) Lutheranism and the Nordic Welfare States in Comparison. Journal of State and Church 56(1): 1-12.

Nieminen A (1981) Piirteitä Heikki Wariksen toiminnasta ja henkilökuvasta. In Jaakkol R, Karisto A, and Roos JP (eds) Sosiaalipolitiikka, historiallinen kehitys ja yhteiskunnan muutos. Espoo: Weilin+Göös, pp. 16-37.

Østergård U (1997) The Geopolitics of Nordic Identity. In Sørensen $\varnothing$ and Stråth B (eds) The Cultural Construction of Norden. Oslo: Scandinavian University Press, pp. 25-71.

Rainio-Niemi J (2009) Yhdistys Heikki Wariksen kaudella 1949-1963. In Jaakkola R, Kainulainen S, and Rahkonen K (eds) Työväensuojelusta sosiaalipolitiikkaan. Sosiaalipoliittinen yhdistys 1908-2008. Helsinki: Edita, pp. 75-94.

Repo V (2011) Ensimmäinen varis joka lensi Atlantin yli. Heikki Waris: sosiaalipolitiikan uranuurtaja. Helsinki: Ville Revon perikunta.

Riihinen O (2009) Pekka Kuusesta Terho Pulkkiseen 1957-1969. In Jaakkola R, Kainulainen S, and Rahkonen K (eds) Työväensuojelusta sosiaalipolitiikkaan. Sosiaalipolittinen yhdistys 1908-2008. Helsinki: Edita, pp. 97-143.

Rothstein B (1998) Just Institutions Matter. The Moral and Political Logic of the Universal Welfare State. Cambridge: Cambridge University Press.

Saari J (1994) Kokonaisvaltainen, kiinteyttävä ja ihmiskeskeinen. Toteutuiko Pekka Kuusen 60-luvun sosiaalipolitiikka? In Ahtiainen P, Räty T, Strömberg J, and Tervonen J (eds) Historia, sosiologia ja Suomi. Yhteiskuntatutkimus itseymmärryksen jäjillä. Helsinki: Hanki ja jää, pp. 115-147.

Sipilä J (1989) Sosiaalityön jäljillä. Helsinki: Tammi.

Stenius H (1997) The Good Life is a Life of Conformity: The Impact of the Lutheran Tradition on Nordic Political Culture. In Sørensen $\varnothing$ and Stråth B (eds) The Cultural Construction of Norden. Oslo: Scandinavian University Press, pp. 161-171. 
Sundback S (1991) Utträdet ur Finlands lutherska kyrka. Kyrkomedlemskapet under religionsfrihet och sekularisering. Åbo: Åbo Akademis förlag.

Tønnessen AV (2000) ... et trygt og godt hjem for alle? Kirkelederes kritikk av velferdsstaten etter 1945. Trondheim: Tapir Akademisk Forlag.

Tønnessen AV (2014) The Church and the Welfare State in Post-War Norway: Political Conflicts and Conceptual Ambiguities. Journal of Church and State 56(1): pp. 13-35.

Varsa E, Szikra D, and Juhász B (2009) Building the 'Social State' in Hungary: The Hungarian Settlement Movement between the Two World Wars. In Hauss G and Schulte D (eds) Amid Social Contradictions. Towards a History of Social Work in Europe. Opladen: Barbara Budrich Publishers.

Waris H (1926) Katsaus settlementtyöhön Suomessa. Ylipainos Sosialisesta Aikakauskirjasta 7. Helsinki.

Waris H (1929) The Settlement Movement in Finland. Helsinki: The Third International Conference of Settlements.

Waris H (1932) Työläisyhteiskunnan syntyminen Helsingin Pitkänsillan pohjoispuolelle I. Helsinki: Suomen historiallinen seura.

Waris H (1934) Työläisyhteiskunnan syntyminen Helsingin Pitkänsillan pohjoispuolelle II. Helsinki: Suomen historiallinen seura.

Waris H (1948) Suomalaisen yhteiskunnan rakenne. Helsinki: Otava.

Waris H (1950) Murrosajan yhteiskuntamme. Suomalainen Suomi 6: 327-332.

Waris H (1951) Sosiaalisen tasauksen pyrkimys. Nykyajan sosiaalipolitiikan kehityssuunnasta. Suomalainen Suomi 8: 453-459.

Waris H (1961) Suomalaisen yhteiskunnan sosiaalipolitiikka. Johdatus sosiaalipolitiikkaan. Helsinki: WSOY.

Waris H (1963) Industrialismin varhainen haaste Suomen kirkolle. Helsingin yliopiston sosiaalipolitiikan laitoksen tutkielmia nro 24.

Waris H (1971) Kirkko kansan omanatuntona. Kristityn ja kirkon sosiaalieettisten ongelmien kartoitus. Helsinki: Weilin + Göös.

Uusi-Rauva S (2008) Vuorovaikutuksen liike. Heikki Waris setlementtiliikkeen historiakuvan rakentajana. Helsinki: Suomen Setlementtiliitto. 